\title{
MIMR RISK FACTORS FOR MEN WHO HAVE SEX WITH MEN AND HIV INCIDENCE IN BUKITTINGGI CITY INDONESIA
}

\author{
Feny Wartisa $^{1 *}$, Neila Sulung ${ }^{2}$, Oktavianis $^{3}$ \\ ${ }^{1}$ STIKes Perintis Padang, Bukittinggi City, West Sumatera, Indonesia \\ 2, ${ }^{3}$ STIKes Fort De Kock Bukittiggi City, West Sumatera, Indonesia \\ *Corresponding Author's Email: fwartisa@gmail.com
}

\begin{abstract}
Men Who Have Sex with Men (MSM) generally cause new HIV infections as much as $12 \%$ in the world in 2015. In Bukittinggi city the findings of new cases of HIV in 2017 were 74 people and among them 40 MSM had risk factors. The purpose of this study was to determine the risk factors for HIV in MSM in the City of Bukittinggi. The design of this study is analytic with a case control approach. The study was conducted on July 23 - August 15, 2018 in the City of Bukittinggi. With a sample size of 60 people with a ratio of $1: 2$, namely 20 case groups and 40 control groups and Snow Ball Sampling technique. Data analysis used is both univariate, bivariate analysis. The high-risk factors behind HIV infection happens due to premature age (46.7\%), low education level $(90 \%)$, unemployment (35\%), low income (48.3\%) and of course marriage $(8.3 \%)$. There is a relationship between age, work and income with HIV infection in MSM. Age, occupation and income are risk factors for HIV incidence in MSM in the City of Bukittinggi.
\end{abstract}

Keywords: HIV, MSM, Risk Factor

\section{INTRODUCTION}

HIV / AIDS is one of the most significant public health challenges in the world, especially in under developed countries (WHO, 2017). HIV is a virus that causes Acquired Immune Deficiency Syndrome (AIDS). This virus attacks the immune system. As a result, the body becomes weak to fight against infection and causes a deficiency in immune system. This leads to various diseases and ultimately can cause death (Noviana, 2016).

According to the 2013 Integrated Biology and Behavior Survey (STBP), this infection mainly causes through the sex workers (both direct and indirect), homosexuals, drug users and transgenders.

Men who have sex with other men (MSM) for financial reasons, sexual desire, various other sexual motives have a greater risk of getting infected with HIV compared to men who have sex with women.

In 2015 MSM has caused 12\% new HIV infection in the world. Meanwhile the prevalence of HIV/AIDS in MSM in Asian countries like China, India, Taiwan and
Nepal is $3.1 \%, 16.8 \%, 8 \%$ and $4 \%$ respectively. In Southeast Asian countries the prevalence of HIV / AIDS in MSM is quite high compared to countries in ASIA namely Thailand (28\%) and Cambodia (14.4\%) (UNAIDS Data, 2017).

In Indonesia prevalence of HIV in MSM from 2010 to 2016 continued to increase, and it amounted to 506 cases in 2010, 1,040 cases in 2011, 1,514 cases in 2012, 3,287 cases in 2013, 3,858 cases in 2014, 4,241 in 2015 and in 2016 there were 13,063. While in West Sumatra MSM in 2015 was the largest in Padang City with 861, Solok City with 522 and Bukittinggi City with 432 people.

Risk factors that influence HIV incidence in MSM are age, education, employment, income and marital status. Younger age has a high risk of contracting HIV $(0.14 \%-0.34 \%)$ compared to older ages (Scott et al., 2015). Low education has a higher risk of getting HIV. There is a significant relationship between income and HIV incidence in MSM in China with $P$ value of 0.001 (Liu et al. 2018). More cases of HIV and AIDS are found in respondents who are married $(73.7 \%)$ and 
$43 \%$ working ones who are especially employees work in private sector (Saktina \& Satriyasa, 2017).

Based on a data from KPA Kota Buktitinggi in 2016, there were 73 new cases of HIV with 36 risk factors for MSM. While in 2017 there were 74 new HIV cases with the highest risk factors for MSM, 57.1\% is followed by high risk couples of $18.9 \%$, LBT (Lesbian, Bisexual and Transgender) of $14 \%$, IDU (Injecting Drugs User) of $8.1 \%$ and male women (transvestites) of $4.1 \%$. Several studies on MSM and HIV have been carried out in the city of Bukittinggi including factors that cause MSM behavior, VCT on MSM and behavioral factors are related to VCT utilization but research on the characteristics of male sex men and HIV events as far as researchers have known that it has not been done in Bukittinggi by other researchers. The purpose of this study was to determine the risk factors for HIV incidence in MSM in the City of Bukittinggi.

\section{METHODOLOGY}

This study uses a case control approach. This study was conducted in the City of Bukittinggi on July 23 to August 15, 2018. The population of this study was all MSM recorded in the KPA in Bukitinggi City in 2017 amounted to 456 people. The sample size in this study was determined using the following formula.

$$
\begin{gathered}
n=\frac{\left\{Z_{1-\alpha / 2} \sqrt{\left[2 P_{2}^{*}\left(1-P_{2}^{*}\right)\right]}+Z_{1-\beta} \sqrt{\left[P_{1}^{*}\left(1-P_{1}^{*}\right)+P_{2}^{*}\left(1-P_{2}^{*}\right)\right]}\right\}^{2}}{\left(P_{1}^{*}-P_{2}{ }^{*}\right)^{2}} \\
P_{1}^{*}=\frac{O R}{(O R+1)} \quad P_{2}^{*}=\frac{P_{1}^{*}}{O R\left(1-P_{1}^{*}\right)+P_{1}^{*}}
\end{gathered}
$$

\section{Information:}

$\mathrm{n}=$ Number of Samples

$\mathrm{P} 1=$ The proportion of exposure in the case group
$\mathrm{P} 2=$ The proportion of exposure in the control group

$\mathrm{Z} \alpha=$ Level of significance (for $=0.05$ is 1.96 )

$\mathrm{Z} \beta=$ Desired power $/$ power level $(0.84)$

This study uses a significant level of $95 \%(\alpha=0.05)$ and a test strength of $80 \%$ using the OR value $=9.06 p$ value 0.009 based on the results of previous studies (Hartono, 2013). Based on the above sample formula, the number of samples was 20 people, with a ratio of $1: 2$ between the case group and the control group, so that the total respondents were 60 people, consisting of 20 case groups and 40 control groups. The case group is male sex men diagnosed with HIV, while the control group is male sex men who are not diagnosed as HIV negative in the city of Bukittinggi. The sampling technique in this study was snowball sampling with Key Informants being Reachers from KPA, Bukittinggi City.

Data was obtained through interviews directly with respondents by using a questionnaire. Respondents were interviewed one by one collected at the cafe from door to door. The variables of this study were age, education level, occupation, income, marital status and HIV incidence. Each variable is measured based on the questionnaire and the respondent's medical records. Age is categorized as high risk $<30$ years and low risk $>$ 30 years. The education level is divided into high and low education levels, employment is divided into work and does not work, income is categorized as high income if 12.1 million (above UMR in Bukittinggi) low if $<2.1$ million. Marital status is categorized as married and single. Data were analyzed by univariate, bivariate analysis after using Chi-suared test to assess the relationship between independent variables and dependent variables, the association was considered significant if the value was $p<0.05$.

\section{RESULTS}

Table: Characteristic Relationships (Age, Education Level, Occupation, Income and marital status) with HIV

\begin{tabular}{|c|c|c|c|c|c|c|c|c|}
\hline \multirow{3}{*}{ Risk Factor } & \multicolumn{4}{|c|}{ HIV Incidence } & \multirow{3}{*}{$\mathbf{N}$} & \multirow{3}{*}{$\%$} & \multirow{3}{*}{$\begin{array}{c}\text { OR } \\
95 \% \mathrm{CI}\end{array}$} & \multirow{3}{*}{$p$ value } \\
\hline & \multicolumn{2}{|c|}{ Case } & \multicolumn{2}{|c|}{ Control } & & & & \\
\hline & $n$ & $\%$ & $n$ & $\%$ & & & & \\
\hline \multicolumn{7}{|l|}{ Age } & \multirow{4}{*}{$\begin{array}{c}4.333 \\
1.364-13.770\end{array}$} & \multirow{4}{*}{0.022} \\
\hline High Risk & 14 & 70 & 14 & 35 & 28 & 46.7 & & \\
\hline Low Risk & 6 & 30 & 26 & 65 & 32 & 53.3 & & \\
\hline Total & 20 & 100 & 40 & 100 & 60 & 100 & & \\
\hline
\end{tabular}
Incidence MSM in the City of Bukittinggi 


\begin{tabular}{|c|c|c|c|c|c|c|c|c|}
\hline Level of Ed & & & & & & & & \multirow{4}{*}{0.653} \\
\hline Low & 19 & 95 & 35 & 87.5 & 54 & 90 & \multirow{3}{*}{$\begin{array}{c}2.714 \\
0.295-24.954\end{array}$} & \\
\hline Height & 1 & 5 & 5 & 12.5 & 6 & 10 & & \\
\hline Total & 20 & 100 & 40 & 100.0 & 60 & 100 & & \\
\hline \multicolumn{9}{|l|}{ Pek Work } \\
\hline Not Working & 12 & 60 & 9 & 35 & 21 & 35 & \multirow{3}{*}{$\begin{array}{c}5.167 \\
1.616-16.520\end{array}$} & \multirow{3}{*}{0.010} \\
\hline Works & 8 & 40 & 31 & 65 & 39 & 65 & & \\
\hline Total & 20 & 100 & 40 & 100 & 60 & 100 & & \\
\hline \multicolumn{9}{|l|}{ Income } \\
\hline Low & 14 & 70 & 15 & 48.3 & 29 & 48.3 & \multirow{3}{*}{$\begin{array}{c}3.889 \\
1.230-12.292\end{array}$} & \multirow{3}{*}{0.036} \\
\hline Height & 6 & 30 & 25 & 51.7 & 31 & 51.7 & & \\
\hline Total & 20 & 100 & 40 & 100.0 & 60 & 100.0 & & \\
\hline \multicolumn{9}{|c|}{ Marital status } \\
\hline Marry & 3 & 15 & 2 & 5 & 5 & 8.3 & \multirow{3}{*}{$\begin{array}{c}3.353 \\
0.512-21.938\end{array}$} & \multirow{3}{*}{0.322} \\
\hline Single & 17 & 85 & 38 & 95 & 55 & 91.7 & & \\
\hline Total & 20 & 100 & 40 & 100 & 60 & 100.0 & & \\
\hline
\end{tabular}

Table shows the characteristic relationship with HIV infection in MSM in the city of Bukittinggi. The proportion of respondents who have high risk age is more in the case group (70\%) compared to the control group (35\%). The results of the statistical analysis showed that there was a relationship between the age of the respondent and the incidence of HIV in MSM ( $p=$ 0.022 ) and the value of OR 4.333. In terms of education level, the proportion of respondents who had a low education level was more in the case group (95\%) compared to the control group (87.5\%). The results of the statistical analysis showed that there was no relationship between the education level of the respondents and the incidence of HIV in MSM ( $p=$ 0.653 ) and $\mathrm{OR}=2.714$. While for the work the proportion of respondents who did not work more in the case group $(60 \%)$ compared to the control group (35\%). The results of the statistical analysis showed that there was a relationship between the work of the respondent and the incidence of HIV in MSM $(p=0.010)$ and OR 5.167. In terms of respondents' income, the proportion of respondents who have low income is more in the case group (70\%) compared to the control group (48.3\%). The results of the statistical analysis showed that there was a relationship between the income of respondents and the incidence of HIV in MSM $(p=0.036)$ and OR 3.889. The results of the statistical analysis showed no relationship between the marital status of respondents with HIV incidence in MSM $(p=0.322)$ and OR 3.353 the proportion of respondents who had marital status more cases (15\%) compared to the control group (5\%).

\section{DISCUSSION}

Adult age will have sexual behavior that is different from the age of adolescence (Kamilah \& Hastono, 2014). The highest HIV infection was found in young MSM. One reason is that young MSM do not have the ability to negotiate safe sex with their sexual partners compared to adult MSM (Agwu et al., 2011). 40.8\% of MSM respondents have ages 18-24 (Thienkrua et al., 2017). Young MSM usually do not have the ability or knowledge in strategies to reduce the risk of transmission to HIV-positive sex partners. Adult MSM are better able to keep themselves uninfected for longer than young MSM. Younger age has a higher risk of contracting HIV/AIDS than older age (Scott et al., 2015). Age is a risk factor for HIV incidence in MSM in Beijing with a $p<0.001$. According to the results of the research, young people are more easily influenced by the environment such as right to live, work and peers. Sometimes the reason for respondents being MSM is because they are invited by friends and by curiosity to have sexual relations with men because sexual relations with men according to them are safer than women because if they have sex with men they will not get pregnant and people will not be suspicious if men are in the same place. 
The level of education is one of the factors that play a role in influencing a person's decision to behave healthy. Someone who is highly educated will be less susceptible to the risk of being infected with HIV and AIDS compared to those who have low education or drop out of school (Annisa \& Harahap, 2011). Higher levels of education will make it easier for someone or community to receive information and implement it in daily life, especially in the health sector (Pratiwi 2015). MSM who study less than 12 years are at 2.12 times more likely to experience HIV seroconversion compared to MSM who have studied more than 12 years $(\mathrm{AHR}=2.12 ; 95 \% \mathrm{CI}=1.12-4.03 ; p=0.02)(\mathrm{Li}$ et al., 2012). But often higher education does not guarantee someone to apply good behavior. $65 \%$ of respondents have low education (Cowan \& Haff 2008). $97.7 \%$ of respondents have low education (Kamilah \& Hastono, 2014). This study is in line with previous studies showing that there was no statistically significant association between the level of education of MSM and the incidence of HIV (IRR $=1.48 ; 95 \% \mathrm{CI}$ $=0.72-3.02)$ (Meireles et al., 2015). In this study the level of education does not always affect a person's health attitudes and behaviors where respondents who are highly educated also become MSM and diagnosed as HIV positive. Peers here are very influential on a person's behavior such as respondents who are initially normal and friends with MSM are also affected so that unnatural sexual activities that result in addiction, become a necessity and ultimately impact HIV / AIDS.

The level of risk of the spread of HIV infection in the community is quite varied depending on each job. The type of work has a role in causing disease (Notoatmodjo, 2012). Communities at risk for the spread of HIV infection are quite diverse such as jobs as laborers, drivers, freelancers and employers are more at risk of being seropositive to HIV than those who do not work (Agarwal et al. 2015). MSM who did not work more in the HIV positive group (29\%) than the HIV negative group (24\%) (MacKellar et al., 2005). This research is in line with previous research which states that the proportion of unemployed HIV positive groups $(43.1 \%)$ is more than HIV negative $(22 \%)$ and there is a relationship between employment status and HIV incidence in MSM $(p=0.02) \mathrm{OR}=2.69$ (Logie et al. 2018). According to the research results, respondents who did not work were more at risk of getting HIV compared to people who worked. Some respondents work as shop employees, substitute employees at salons with mediocre salaries while the necessities of life are quite high, if they open their own jobs such as workshops or open their own salons they have no special skills and do not have the capital to open a business. So that not a few respondents fall into the practice of prostitution to earn a large income and eventually get sexually transmitted diseases, especially HIV.

Income is closely related to work. MSM who work have their own income so they can meet their needs. High economic needs and not in accordance with income can plunge someone into deviant behavior is not likely to become a sex seller. The proportion of HIV events in the case group with less socio-economic respondents $(70.4 \%)$ was greater than the control group respondents with less socio-economic $(56.3 \%)$. The results of this study are in line with previous studies showing that there is a relationship between income and HIV incidence in MSM $(p=0.001)$ (Liu et al., 2018).

Marriage is not enough to protect themselves from HIV infection (Gray et al. 2004). Married MSM do not show sexual practices towards their wives, whether to avoid homophobia, fear of stigma and discrimination, selfshame or other sexual customs (Solomon et al., 2010). This research is in line with previous research which found that there was no significant difference in HIV prevalence between married MSM compared to unmarried MSM (Setia et al. 2010). In contrast to research conducted by Bongaarts found that HIV prevalence was higher in married people $(8 \%)$ compared to unmarried people (4.7\%) (Bongaarts, 2007). People who were once married (widows / widowers) have the highest level of HIV infection (23.7\%). Kumta's research in Mumbai states that married MSM are more at risk of being seropositive (Kumta et al. 2010). Based on the results of the study, most of the respondents had unmarried status due to their lack of interest in the opposite sex, MSM idolized more mature and protective male figures because men understood men better and some MSM had experienced broken hearts with women so that they prefer men as mates. However, some of them have future hopes to get married at the age of 30 years.

\section{CONCLUSION AND RECOMMENDATION}

The results of this study can be concluded that age, occupation and income are risk factors for HIV 
incidence in MSM in the city of Bukittinggi. In this case, it is suggested that the Regional Government of the City of Bukittinggi make regional regulations relating to LGBT, especially MSM, and it is expected that the Health Office of the city of Bukittinggi will disseminate information to improve communication, information and education on HIV transmission and prevention not only to individuals and groups but also to the community such as families, schools, community leaders.

\section{REFERENCES}

Agarwal, A., Hamdallah, M., Swain, S.N., Mukherjee, S., Singh, N., Mahapatra, S., King, E.J., Pulerwitz, J. \& Thior, I. (2015). Implementation of a confidential helpline for men having sex with men in India. JMIR Mhealth and Uhealth, 3(1), pages 12.

Agwu, E., Pazos, V., Ihongbe, J.C. \& Ssengendo, J. (2011). Appraisal of the Inherent SocioDemographic Dynamics of HIV/AIDS Epidemic in Four Districts of South-Western Uganda. SAHARAJ: Journal of Social Aspects of HIV/AIDS, 8(3), pp 150-155, doi: 10.1080/17290376.2011.9724997.

Annisa, T.\& Harahap. (2011). Gambaran Dan FaktorFaktor Yang Mempengaruhi Kejadian HIV Pada Wanita Penjaja Seks Komersial (WPSTL) Di Kota Batam Dan Kota Denpasar Tahun 2011= Description and Factors of Indirect Sex Worker with HIV in Batam and Denpasar City in 2011. Retrieved from: http://lib.ui.ac.id/ file? file= pdf/abstrak-20331676.pdf

Bongaarts, J. (2007). Late Marriage and the HIV Epidemic in Sub-Saharan Africa. Population Studies, 61 (1), pp 73-83.

Cowan, S.A.\& Haff, J. (2008). HIV and risk behaviour among men who have sex with men in Denmark-the 2006 Sex Life Survey. Euro Surveillance, 13(48)

Gray, R.H., Li, X., Wawer, M.J., Serwadda, D., Sewankambo, N.K., Wabwire-Mangen, F., Lutalo, T., Kiwanuka, N., Kigozi, G., Nalugoda, F., Meehan, M.P., Robb, M.\& Quinn, T.C. (2004). Determinants of HIV-1 load in subjects with early and later HIV infections, in a general-population cohort of Rakai, Uganda. The Journal of Infectious Diseases, 189(1), pp 1209-1215
Hartono, A. (2013). Faktor Risiko Kejadian Penyakit Menular Seksual (Pms) Pada Komunitas Gay Mitra Strategis Perkumpulan Keluarga Berencana Indonesia (Pkbi) Yogyakarta. Retrieved from: http://eprints.ums.ac.id/5967/1/J410050023.PDF? jumlah-pms-yogyakarta.pdf

Kamilah, E.M.\& Hastono, S.P.(2014). Hubungan Karakteristik Pasien, Perilaku Beresiko Dan Infeksi Menular Seksual Dengan Kejadian HIV/ AIDS Di Klinik VCT ( Voluntary Counselling and Testing ) Puskesmas Cikarang Kecamatan Cikarang Utara Kabupaten Bekasi Tahun 2013 Abstrak Relations Patient. Retrieved from: http://lib.ui.ac.id/naskahringkas/2016-06/S55224Eulis\%20Mar\%20Atul\%20Kamilah

Kumta, S., Lurie, M., Weitzen, S., Jerajani, H., Gogate, A., Row-kavi, A., Anand, V., Makadon, H.\& Mayer, K.H.(2010). Bisexuality, sexual risk taking, and HIV prevalence among men who have sex with men accessing voluntary counseling and testing services in Mumbai, India. Journal of Acquired Immune Deficiency Syndrome,53(2), pp 227-233

Li, D., Li, S., Liu, Y., Gao, Y., Yu, M., Yang, X., Li, Q., Jiang, S., Zhou, Z., Zhnag, Z., Yan, L., Jiang, G., Xiao, D., Pan, S.W., Luo, F., Ruan, Y.\& Shao, Y. (2012). HIV incidence among men who have sex with men in Beijing: a prospective cohort study. BMJOpen, Pages 7

Liu, Y., Vermund, S.H., Ruan,Y., Liu,H., Zhang,C., Yin,L., Shao, Y.\& Quian, H.Z.(2018). HIV Testing and Sexual Risks among Migrant Men Who Have Sex with Men: Findings from a Large CrossSectional Study in Beijing, China. AIDS Care, 30 (1), pp 86-94

Logie, C.H., Kenny, K.S., Lacombe-Duncan, A., Levermore, K., Jones, N., Neil, A., Ellis, T., Marshall, A.\& Newman, P.A. (2018). Social-ecological factors associated with HIV infection among men who have sex with men in Jamaica. International Journal of STD\& AIDS, 29(1), pp 80-88

MacKellar, D.A., Valleroy, L.A., Secura, G.M., Behel, S., Bingham, T., Celentano, D.D., Koblin, B.A., Lalota, M., McFarland, W., Shehan, D., Thiede, H., Torian, L.V., Janssen, R.S.\& Young Men's Survey Study Group.(2005). Unrecognized HIV infection, 
risk behaviors, and perceptions of risk among young men who have sex with men: opportunities for advancing HIV prevention in the third decade of HIV/AIDS. Journal of Acquired Immuno Deficiency Syndromes, 38(5), pp 603-614

Meireles, P., Lucas, R., Carvalho, C., Fuertes, R., Brito, J., Campos, M.J., Mendão, L.\& Barros, H. (2015). Incident risk factors as predictors of HIV seroconversion in the Lisbon cohort of men who have sex with men: first results, 2011-2014. Euro Surveillence, pages 12

Notoatmodjo, S. (2012). Metodologi Penelitian Kesehatan. Jakarta: Rineka Cipta

Noviana, N. (2016). The concept of HIV / AIDS, Sexuality and Reproductive Health.

Pratiwi, N.K. (2015). Pengaruh Tingkat Pendidikan, Perhatian Orang Tua, Dan Minat Belajar Siswa Terhadap Prestasi Belajar Bahasa Indonesia Siswa Smk Kesehatan Di Kota Tangerang. Journal Pujangga, 1(2), pp 75-105.

Saktina, P.U.\& Satriyasa, B.K.(2017). Karakteristik Penderita Aids Dan Infeksi Oportunistik Di Rumah Sakit Umum Pusat Sanglah Denpasar Periode Juli 2013 Sampai Juni 2014. E-Journal Medika,6(3),pp $1-6$

Scott, H.M., Vittinghoff, E., Irvin, R., Sachdev, D., Liu, A., Gurwith, M. \& Buchbinder, S.P. (2015). Age, Race/Ethnicity, and Behavioral Risk Factors Associated with Per-Contact Risk of HIV Infection Among Men Who Have Sex with Men in the United States. Journal of Acquired Immune Deficiency Syndromes, 65 (1), pp 115-121
Setia, M.S., Sivasubramanian,M., Anand, V., RowKavi, A. \& Jerajani, H.R. (2010). Married Men Who Have Sex with Men: The Bridge to HIV Prevention in Mumbai, India. International Journal of Public Health, 55 (6), pp 687-691.

Solomon,S.S., Mehta,S.H., Latimore, A., Srikrishnan, A.K. \& Celentano, D.D.(2010). The impact of HIV and high-risk behaviours on the wives of married men who have sex with men and injection drug users: implications for HIV prevention. Journal of the International AIDS Society, 13(Suppl 2), pp 2-8

Thienkrua, W.,van Griensven, F., Mock, P., Dunne, E., Raengsakulrach, B., Wimonsate, W., Howteerakul, N., Ungsedhapand, C., Chiwarakorn, A.\& Holtz, T.H.(2018).Young Men Who Have Sex with Men at High Risk for HIV, Bangkok MSM Cohort Study, Thailand 2006-2014. AIDS and Behaviour, 22(7), pp 2137-2146

Treat Asia.(2006).MSM and HIV/AIDS Risk in Asia: What is Fueling the Epidemic Among MSM and How Can It Be Stopped? Retrieved from: file:///C:/Users/LUC-KOL/Desktop/ Special Report_2006-08_MSM-HIVRiskInAsia.pdf

Tuti, S. (2011). Faktor - Faktor Risiko Yang Berpengaruh Terhadap Kejadian HIV Dan AIDS Di Semarang Dan Sekitarnya. Journal Komunikasi Kesehatan, 2(1), pp 1-16.

UNAIDSData2017.(2017).ProgrammeonHIV/AIDS. Retrievedfrom:https://www.unaids.org/sites/defau 1t/files/media_asset/20170720_Data_book_2017 en.pdf

WHO. (2017). 10 Facts on HIV/AIDS. Retrieved from: http://origin.who.int/features/factfiles/hiv/en/ 